УДК 632.3/.4

DOI https://doi.org/10.32848/agrar.innov.2021.10.5

\title{
ЗНИЖЕННЯ УРАЖЕНОСТІ РОСЛИН СІЛЬСЬКОГОСПОДАРСЬКИХ КУЛЬТУР ХВОРОБАМИ ЗА МІКОРИЗАЦІЇ ГРИБАМИ ТА СИМБІОЗУ 3 АЗОТФІКСУЮЧИМИ БАКТЕРІЯМИ ЇХ КОРЕНЕВОЇ СИСТЕМИ
}

\author{
ДИмитРОВ С.Г. - кандидат сільськогосподарських наук \\ https://orcid.org/0000-0002-0377-9596 \\ Національний університет біоресурсів і природокористування \\ САБЛУК В.Т. - доктор сільськогосподарських наук, профресор \\ https://orcid.org/0000-0002-6124-4346 \\ Інститут біоенергетичних культур і цукрових буряків \\ ТАНЧИК С.П. - доктор сільськогосподарських наук, професор, \\ член-кореспондент Національної академії аграрних наук України \\ https://orcid.org/0000-0002-4975-7720 \\ Національний університет біоресурсів і природокористування
}

Вступ. Широке застосування біопрепаратів у практиці сільського господарства обмежується їх несумісністю з більшістю хімічних засобів захисту рослин від хвороб. Санітарний стан сучасного насінництва залишає бажати кращого, і скільки б не намагались досягти високого та якісного врожаю за рахунок оптимізації живлення рослин, ураження хворобами зведе нанівець усі зусилля. Тому протруєння посівного матеріалу $\epsilon$ обов'язковим агроприйомом [1].

Деякі представники ризосферних і ендофітних бактерій проявляють антагоністичні властивості до фітопатогенів і підвищують імунітет рослин, тому ця властивість широко застосовується у світовій практиці $[2,3]$. Чимало штамів азотфіксувальних і фоссформобілізуючих мікроорганізмів також мають аналогічну здатність $[4,5]$.

Пошук нових біологічних препаратів триває, і обробка насіння мікробними біофунгіцидами на основі окремих штамів - представників родів Bacillus, Pseudomonasi Trichodermay - уможливило зниження ураженості насіння зернових культур збудниками кореневих гнилей на $62 \%$, фузаріозів - на $63 \%$, альтернаріозів - на $56 \%$, мікроміцетів - на 49\% [6, 7].

Хімічний метод захисту рослин, хоч і продовжує займати провідне місце в арсеналі заходів боротьби, внаслідок властивих йому недоліків поступово витісняється екологобезпечними біологічними препаратами [8], ефективними проти шкідливих організмів.

Значне місце у підвищенні продуктивності і стійкості сільськогосподарських культур до хвороб приділяється біопрепаратам на основі біологічно активних речовин, зокрема регуляторам росту. Вони разом із фрітостимулювальною дією через здатність активувати обмін речовин та брати участь в окисно-відновлювальних процесах впливають на стійкість рослин до шкідливих організмів [9-11].

Крім того, мікробні препарати сприяють зростанню чисельності мікроорганізмів окремих еколого-трофрічних груп у ризосфрерному ґрунті, що опосередковано свідчить про метаболічні зміни бактеризованих рослин, та покращують продукційний процес сільськогосподарських культур [12-14].

Отже, правильне застосування біопрепаратів окремо і в комплексі дозволить істотно знизити хімічне навантаження на екосистеми, значно поліпшити якість сільськогосподарської продукції i, зрештою, здоров'я людини.

Meта досліджень - встановити вплив мікорізації кореневої системи рослин сільськогосподарських культур на зменшення їх ураженості найбільш поширеними хворобами.

Матеріали та методика досліджень. Дослідження проводили в Інституті біоенергетичних культур і цукрових буряків НААН України в умовах Веселоподільської дослідно-селекційної станції (ВПДСС), яка знаходиться на Лівобережжі Дніпра в зоні типового Лісостепу. Ґрунтовий покрив відзначається строкатістю - переважають чорноземи солонцюваті та слабосолонцюваті.

Для дослідів використовували гриби везикулярно-арбускулярної мікоризації Tuber melanosporum Vittad. (препарат Міковітал) та Trichoderma harzianum Rifai (препарат Мікофренд) і бактерії Bacillus subtilis Cohn. (препарат Флоробацилін).

Досліди проводили у 4-кратній повторності, площа

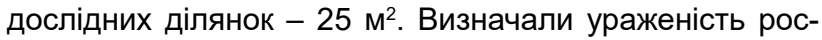
лин пшениці озимої кореневими гнилями, борошнистою росою та іржею, а рослини кукурудзи - пухирчастою сажкою, гельмінтоспоріозом листя й іржею.

Зокрема, для визначення ураженості кореневої системи рослин пшениці озимої гнилями на захисній смузі кожної повторності викопували по 10 рослин, кореневу систему обрізали до кореневої шийки, очищали від землі, промивали водою і візуально визначали наявність хвороб і ступінь їх розвитку за формулами.

Поширеність хвороби (P) у варіантах:

$$
P=\frac{y * 100}{n}(1)
$$

де У - кількість уражених хворобою рослин, шт;

$\mathrm{n}$ - загальна кількість рослин у пробі.

Ступінь розвитку хвороб $(R)$ у відсотках:

$$
R=\frac{(a * b)}{n}(2)
$$

$\mathrm{n}$ - загальна кількість рослин у пробі, шт;

(a*b) - сума добутків кількості рослин на відповідний їм бал ураженості. 
Для визначення ураженості іншими хворобами на кожній повторності відбирають підряд у рядку по 10 рослин і візуально визначають процент уражених рослин і ступінь розвитку тієї чи іншої хвороби за фрормулами 1 і 2.

Результати досліджень. Як свідчать дані таблиць 1 і 2, у варіантах із мікоризоутворювальними грибами й азотфіксувальними бактеріями ураженість рослин сільськогосподарських культур хворобами істотно менша порівняно з контролем.

Зокрема, ураженість рослин пшениці озимої кореневими гнилями у варіантах із грибами (препарати Мікофренд і Міковітал) і бактеріями (препарат Флоробацилін) була за поширеністю на 4,4-6,5\%, а за розвитком - на 3,0-3,2\% меншою, ніж у контролі. Так само це стосується ураженості листків цих культур борошнистою росою і бурою іржею. Різниця з показниками у варіантах із препаратом Мікофренд і контролем становила відповідно за поширеністю 9,9-21,1\%, а за розвитком - 5,3-10,4\%. У варіантах із препаратом Флоробацилін - 9,0-15,9\% і 5,5-8,8\%, а з препаратом Міковітал - 11,3-18,3\% і 6,7-8,6\% (табл. 1).

У посівах кукурудзи відзначали ураженість рослин пухирчастою сажкою, гельмінтоспоріозом та іржею (табл. 2).

У варіантах із мікоризоутворювальними грибами й азотфріксувальними бактеріями поширеність цих хвороб і їх розвиток були істотно меншими порівняно з контролем. Так, у варіантах із препаратом Мікофренд (гриб Trichoderma harzianum Rifai) поширеність пухирчастої сажки становила $4,1 \%$, а розвиток хвороби $2,5 \%$, що на $3,7-5,8 \%$ менше, ніж у контролі. Різниця у показниках ураженості рослин гельмінтоспоріозом і іржею між дослідом і контролем у варіантах із цим препаратом була значно відчутною, ніж у показниках згаданої вище хвороби, і становила 11,9-22,9\%.

Щодо показників урожайності рослин цими хворобами у варіантах із препаратами Флоробацилін і Міковітал, то вони також помітно різняться порівняно з контролем. Зокрема, у варіантах із препаратом Міковітал ця різниця становила за поширеністю $18,8-20,9 \%$, а за розвитком - 11,0-13,8\%. У варіантах із препаратом Флоробацилін ці показники різниці між дослідом і контролем були дещо нижчими, ніж у варіантах із препаратом Міковітал, і становили відповідно 4,9-15,2\% і 1,4-8,6\%. При цьому різниця в ураженості рослин пухирчастою сажкою за її розвитком становила всього 1,4\%, що за межею достовірності (P-level становив 0,07 за межі достовірності 0,05) у таблиці 3 .

Причиною зниження ураженості рослин пшениці м'якої озимої і кукурудзи звичайної хворобами можна вважати підвищену їх здатність протистояти розвитку збудників цих хвороб за рахунок більшої маси кореневої системи і листкового апарату, а тому кращого забезпечення поживними речовинами і вологою, більш інтенсивного процесу фотосинтезу тощо порівняно з контролем.

Зокрема, за даними наших досліджень, маса кореневої системи цих рослин у різні терміни вегетації у варіантах із мікоризоутворювальними грибами й азотфріксувальними бактеріями була на 51,9-130,1\%, а площа листкової поверхні - на 29,4-54,4\% більшою, ніж у контролі.

Крім того, є висловлювання окремих дослідників про те, що мікориза дає сигнал рослині про можливість її зараження тією чи іншою хворобою, а та шукає варіант протидії цьому процесу.

Таблиця 1

Ураженість рослин пшениці озимої за мікоризації їі кореневої системи (ВПДСС), 2017-2022 рр.

\begin{tabular}{|c|c|c|c|c|c|c|c|c|c|c|c|c|c|c|}
\hline \multirow[b]{3}{*}{ Хвороби } & \multicolumn{14}{|c|}{ Ураженість рослин хворобами, \% } \\
\hline & \multicolumn{2}{|c|}{ контроль } & \multicolumn{4}{|c|}{ мікофрренд } & \multicolumn{4}{|c|}{ фолоробацилін } & \multicolumn{4}{|c|}{ міковітал } \\
\hline & 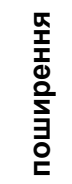 & 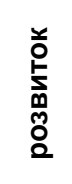 & 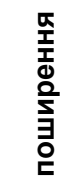 & 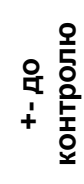 & 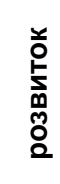 & 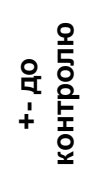 & 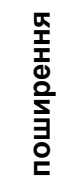 & 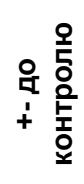 & 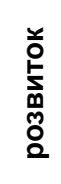 & 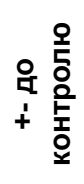 & 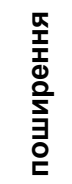 & 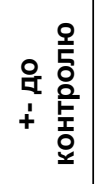 & 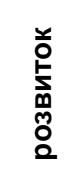 & 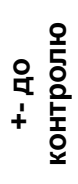 \\
\hline Кореневі гнилі & 12,0 & 5,4 & 5,5 & 6,5 & 2,4 & 3,0 & 7,6 & 4,4 & 2,3 & $-3,1$ & 6,8 & $-5,2$ & 2,2 & $-3,2$ \\
\hline Борошниста роса & 16,4 & 8,9 & 6,5 & $-9,9$ & 3,6 & $-5,3$ & 7,4 & $-9,0$ & 3,4 & $-5,5$ & 5,1 & $-11,3$ & 2,2 & $-6,7$ \\
\hline Бура іржа листя & 32,7 & 16,1 & $-11,6$ & $-21,1$ & 5,7 & $-10,4$ & 16,8 & $-15,9$ & 7,3 & $-8,8$ & 14,4 & $-18,3$ & 17,5 & $-8,6$ \\
\hline
\end{tabular}

Ураженість рослин кукурудзи звичайної за мікоризації її кореневої системи (ВПДСС), 2017-2022 рр.

\begin{tabular}{|c|c|c|c|c|c|c|c|c|c|c|c|c|c|c|}
\hline \multirow[b]{3}{*}{ Хвороби } & \multicolumn{14}{|c|}{ Ураженість рослин хворобами, \% } \\
\hline & \multicolumn{2}{|c|}{ контроль } & \multicolumn{4}{|c|}{ мікофренд } & \multicolumn{4}{|c|}{ флоробацилін } & \multicolumn{4}{|c|}{ міковітал } \\
\hline & 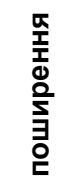 & 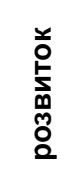 & 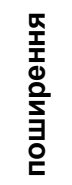 & 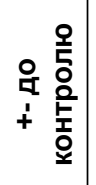 & 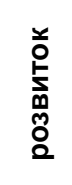 & 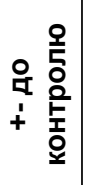 & 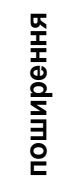 & 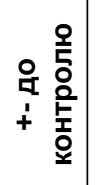 & 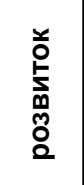 & 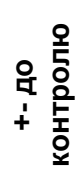 & 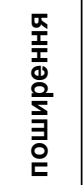 & 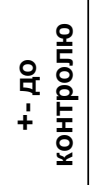 & 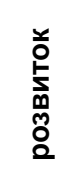 & 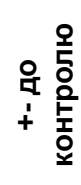 \\
\hline Сажка пухирчаста & 2,6 & 1,2 & 1,1 & $-1,5$ & 0,5 & $-0,7$ & 1,7 & $-0,9$ & 0,8 & $-0,4$ & 1,4 & $-1,1$ & 0,7 & $-0,5$ \\
\hline Гельмінтоспоріоз листків & 46,0 & 23,2 & 33,1 & $-12,9$ & 16,8 & $-6,3$ & 31,9 & $-14,0$ & 16,7 & $-6,5$ & 30,9 & $-15,1$ & 16,4 & $-6,7$ \\
\hline Іржа & 36,3 & 19,4 & 25,0 & $-11,3$ & 13,5 & $-6,0$ & 31,1 & $-5,2$ & 16,8 & $-2,7$ & 28,8 & $-7,5$ & 15,4 & $-4,1$ \\
\hline
\end{tabular}


P-level пшениці озимої та кукурудзи, ВПдСС, 2017-2022 рр.

\begin{tabular}{|c|c|c|c|c|c|c|}
\hline \multirow{2}{*}{ за розвитком } & \multicolumn{3}{|c|}{ Пшениця озима } & \multicolumn{3}{c|}{ Кукурудза } \\
\cline { 2 - 7 } & Мікофренд & Флоробацилін & Міковітал & Мікофренд & Флоробацилін & Міковітал \\
\hline 30 & 0,03 & 0,03 & 0,03 & 0,03 & 0,07 & 0,02 \\
\hline 60 & 0,02 & 0,02 & 0,01 & 0,007 & 0,01 & 0,006 \\
\hline 90 & 0,008 & 0,009 & 0,009 & 0,008 & 0,009 & 0,008 \\
\hline
\end{tabular}

\section{Висновки}

1. За використання мікоризоутворюальних грибів Tuber melanosporum Vittad. та Trichoderma harzianum Rifai і бактерії Bacillus subtilis Cohn. ураженість рослин пшениці м'якої озимої і кукурудзи звичайної хворобами істотно зменшується порівняно з контролем.

2. Основною причиною зменшення ураженості рослин цих культур хворобами за мікоризації їх кореневої системи є їхня здатність протидіяти зараженню патогенами за рахунок підвищеної життєдіяльності через покращення забезпечення елементами живлення і вологою і більш інтенсивного, ніж у контролі, процесу фотосинтезу.

\section{СПИСОК ВИКОРИСТАНОЇ ЛІТЕРАТУРИ:}

1. Гончар Н.В., КаменєВ І.В., Клочко В.С. Мікробні препарати як один із елементів технології вирощування сільськогосподарських культур. Проблеми конструювання, виробництва та експлуатації сільськогосподарської техніки: матер. Х Міжнар. наук.-практ. конф. (м. Кіровоград, 5-6 лист. 2015 р.). Кіровоград: КНТУ, 2015. С. 61-62.

2. Killian M., Jungle H., Steiner U., Krieg U. Einfluss von Umweltfaktoren auf die ertragssteigernde Wirkung von FZB24 Bacillus subtilis bei Kartoffeln. Mitteilungen aus der Biologischen Bundesanstalt für Land- und Forstwirtschaft. Berlin-Dahlem, 1998. Nr. 357. S. 361.

3. Schmiedeknecht G., Jungle $H_{\text {., }}$ Grosch R., Bochow $\mathrm{H}$. Anwendungsmöglichkeiten von Bacillus subtilis für den biologischen Pflanzenschutz. Mitteilungen aus der Biologischen Bundesanstalt für Land- und Forstwirtschaft. Berlin-Dahlem, 1998. Nr. 357. S. 354.

4. Дятлов К.Д. Микробные препараты в растениеводстве. Соросовский образовательный журнал. 2001. T. 7, № 5. С. 17-22.

5. Патика В.П., Тихонович І.А., Філіп'єв І.Д. та ін. Мікроорганізми і альтернативне землеробство / за ред. В.П. Патики. Київ: Урожай, 1993. 176 с.

6. Кузин А.И., Кириченко П.М., Кузнецова Н.И. Фунгицидные свойства штамма Bacillus subtilis. Сельскохозяйственная микробиология в XIXXXI веках: тез. докл. Всерос. конф. (г. СанктПетербург, 14-19 июня 2001 г.). Санкт-Петербург: Изд-во ВНИИСХМ, 2001. С. 30.

7. Курдиш І.К., Рой А.О., Бега З.Т., Булавенко Л.В. Гранульовані мікробні препарати комплексної дії на рослини. Збірник наукових праць Уманського державного аграрного університету. 2003. Спец. вип. С. 267-270.

8. Соколов М.С. Состояние, проблемы и перспективы применения экологически безопасных пестицидов в растениеводстве. Агрохимия. 1990. № 10. C. $124-145$.
9. Пономаренко С.П., Анішин Л.А., Оверченко Б.П. Висока безпека - висока віддача. Вплив регуляторів росту на врожайність і стійкість рослин проти шкідників та збудників хвороб. Захист рослин. 2003. № 12. С. 17-18.

10. Меркушина А.С. Використання регуляторів росту в імунітеті рослин. Збірник наукових праць, присвячений 100-річчю з дня народження С.С. Рубіна / за ред. В.О. Єщенко, П.Г. Копитко. Умань: УСГА, 2000. C. 226-229.

11. Пономаренко С.П. Регулятори росту рослин на основі N-оксидів похідних піридину (фізико-хімічні властивості й біологічна активність). Київ: Техніка, 1999. 272 c.

12. Иутинская Г.А., Остапенко А.Д., Андреюк Е.И. Устойчивость микробных сообществ почвы под озимой пшеницей при разных агротехнологиях ее возделывания. Мікробіологічний журнал. 1993. Т. 55, № 2. C. 3-7.

13. Патика В.П., Коць С.Я., Волкогон В.В. та ін. Біологічний азот / за ред. В.П. Патики. Київ: Світ, 2003. 422 c.

14. Волкогон В.В., Надкернична О.В., Ковалевська Т.М. та ін. Мікробні препарати у землеробстві. Теорія і практика / за ред. В.В. Волкогона. Київ: Аграрна наука, 2006. 312 с.

\section{REFERENCES:}

1. Honchar, N.V., Kameniev, I.V., \& Klochko, V.S. (2015, November). Mikrobni preparaty yak odyn iz elementiv tekhnolohii vyroshchuvannia silskohospodarskykh kultur [Microbial preparations as one of the elements of technology of cultivation of agricultural crops]. Problemy konstruiuvannia, vyrobnytstva ta ekspluatatsii silskohospodarskoi tekhniky: materialy $X$ Mizhnarodnoi naukovo-praktychnoi konferentsii [Problems of design, production and operation of agricultural machinery: materials of the $X$ International scientific-practical conference] (pp. 61-62). Kirovohrad: KNTU [in Ukrainian].

2. Killian, M., Jungle, H., Steiner, U., \& Krieg, U. (1998). Einfluss von Umweltfaktoren auf die ertragssteigernde Wirkung von FZB24 Bacillus subtilis bei Kartoffeln. Mitteilungen aus der Biologischen Bundesanstalt für Land- und Forstwirtschaft. Berlin-Dahlem, 357, 361.

3. Schmiedeknecht, G., Junge, H., Grosch, R., \& Bochow, H. (1998). Anwendungsmöglichkeiten von Bacillus subtilis für den biologischen Pflanzenschutz. Mitteilungen aus der Biologischen Bundesanstalt für Land- und Forstwirtschaft. Berlin-Dahlem, 357, 354.

4. Schmiedeknecht, G., Jungle, H., Grosch, R., \& Bochow, H. (1998). Anwendungsmöglichkeiten von Bacillus subtilis für den biologischen Pflanzenschutz. Mitteilungen aus der Biologischen Bundesanstalt für Land- und Forstwirtschaft. Berlin-Dahlem, 357, 354. 
5. Dyatlov, K.D. (2001). Mikrobnye preparaty v rastenievodstve [Microbe preparations in plant growing]. Sorosovskiy obrazovatel'nyy zhurnal - Soros educational journal, 7(5), 17-22 [in Russian].

6. Patyka, V.P., Tykhonovych, I.A., Filipiev, I.D., Hamaiunova, V.V., \& Andrusenko, I.I. (1993). Mikroorhanizmy i alternatyvne zemlerobstvo [Microorganisms and alternative farming]. V.P. Patyka (Ed.). Kyiv: Urozhai [in Ukrainian].

7. Kuzin, A.I., Kirichenko, P.M., \& Kuznetsova, N.I. (2001 June). Fungitsidnye svoystva shtamma Bacillus subtilis [Fungicidal properties of the Bacillus subtilis strain]. Sel'skokhozyaystvennaya mikrobiologiya $v$ XIX-XXI vekakh: tezisy dokladov Vseros. konf. [Agricultural microbiology in the XIX-XXI centuries: abstracts of the All-Russian conference] (p. 30). Sankt-Peterburg: VNIISKhM Publ. [in Russian].

8. Kurdysh, I.K., Roi, A.O., Beha, Z.T., \& Bulavenko, L.V. (2003). Hranulovani mikrobni preparaty kompleksnoi dii na roslyny [Granular microbial preparations of complex action on plants]. Zbirnyk naukovykh prats Umanskoho derzhavnoho ahrarnoho universytetu [Collection of scientific works of Uman State Agrarian University], Special issue, 267-270.

9. Sokolov, M.S. (1990). Sostoyanie, problemy i perspektivy primeneniya ekologicheski bezopasnykh pestitsidov $\checkmark$ rastenievodstve [Status, problems and prospects of using environmentally friendly pesticides in crop production]. Agrokhimiya - Agrochemistry, 10, 124-145 [in Russian].

10. Ponomarenko, S.P., Anishyn, L.A., \& Overchenko, B.P. (2003). Vysoka bezpeka - vysoka viddacha. Vplyv rehuliatoriv rostu na vrozhainist i stiikist roslyn proty shkidnykiv ta zbudnykiv khvorob [High security - high return. Influence of growth regulators on yield and resistance of plants against pests and pathogens]. Zakhyst roslyn Plant protection, 12, 17-18 [in Ukrainian].

11. Merkushyna, A.S. (2000). Vykorystannia rehuliatoriv rostu $v$ imuniteti roslyn [The use of growth regulators in plant immunity]. Zbirnyk naukovykh prats, prysviachenyi 100-richchiu z dnia narodzhennia S.S. Rubina [Collection of scientific works dedicated to the 100th anniversary of the birth of S.S. Rubin] (pp. 226-229). V.O. Yeshchenko, P.H. Kopytko (Eds.). Uman: USAA [in Ukrainian].

12. Ponomarenko, S.P. (1999). Rehuliatory rostu roslyn na osnovi N-oksydiv pokhidnykh pirydynu (fizyko-khimichni vlastyvosti y biolohichna aktyvnist) [Plant growth regulators based on $\mathrm{N}$-oxides of pyridine derivatives (physicochemical properties and biological activity)]. Kyiv: Tekhnika [in Ukrainian].

13. lutinskaya, G.A., Ostapenko, A.D., \& Andreyuk, E.I. (1993). Ustoychivost' mikrobnykh soobshchestv pochvy pod ozimoy pshenitsey pri raznykh agrotekhnologiyakh ee vozdelyvaniya [Stability of soil microbial communities under winter wheat with different agrotechnologies of its cultivation]. Mikrobiolohichnyi zhurnal - Microbiological Journal, 55(2), 3-7 [in Russian].

14. Patyka, V.P., Kots, S.Ya., Volkohon, V.V., Sherstoboieva, O.V., Melnychuk, T.M., Kalinichenko,A.V., \& Hrynyk, I.V. (2003). Biolohichnyi azot [Biological nitrogen]. V.P. Patyka (Ed.). Kyiv: Svit [in Ukrainian].

15. Volkohon, V.V., Nadkernychna, O.V., Kovalevska, T.M., Tokmakova, L.M., Kopylov, Ye.P., Kozar, S.F., ...
Khalep, Yu.M. (2006). Mikrobni preparaty u zemlerobstvi. Teoriia i praktyka [Microbial preparations in agriculture. Theory and practice]. V.V. Volkohon (Ed.). Kyiv: Ahrarna nauka [in Ukrainian].

Димитров С.Г. Саблук В.Т., Танчик С.П. Зниження ураженості рослин сільськогосподарських культур хворобами за мікоризації грибами та симбіозу 3 азотфісуючими бактеріями їх кореневої системи

Мета. Встановити вплив мікорізації та азотфріксації кореневої системи рослин сільськогосподарських культур на зменшення їх ураженості найбільш поширеними хворобами. Методи. Польові, лабораторні та статистичні. Результати. За результатами проведених досліджень встановлено, що мікоризація кореневої системи рослин сільськогосподарських культур істотно впливає на зниження їх ураженості найбільш поширеними хворобами. Зокрема, за використання мікоризоутворювальних грибів Trichoderma harzianum RIFAl та Tuber melanosporum Vittad. і азотфіксувальних бактерій Bacillus subtilis Cohn. (препарати Мікофренд, Міковітал і Флоробацилін) отримано позитивні результати щодо зниження ураженості рослин пшениці м'якої озимої і кукурудзи звичайної такими небезпечними хворобами, як кореневі гнилі, борошниста роса, бура іржа, пухирчаста сажка, гельмінтоспоріоз тощо. Так, у варіантах із препаратами Мікофренд, Міковітал і Флоробацилін ураженість хворобами рослин пшениці м'якої озимої і кукурудзи звичайної за поширеністю була на 4,4-21,3\%, а за розвитком - на 3,0-13,8\% меншою, ніж у контролі. Особливо відчутним було зниження ураженості рослин пшениці озимої і кукурудзи іржею і гельмінтоспоріозом, яке у варіантах із мікоризоутворювальними грибами і бактеріями становило за поширеністю 15,2-21,3\%, а за розвитком - 8,6-13,8\% порівняно 3 контролем. Висновки. Основною причиною зменшення ураженості рослин цих культур хворобами за мікоризації їх кореневої системи $€$ їхня здатність протидіяти зараженню патогенами за рахунок підвищеної життєдіяльності через покращення забезпечення елементами живлення і вологою і більш інтенсивного, ніж у контролі, процесу фотосинтезу.

Ключові слова: рослини, гельмінтоспоріоз, бура іржа, пухирчаста іржа, кореневі гнилі, поширеність, хвороби, мікоризоутворювальні гриби, бактерії, ураженість.

Dymytrov S.H. Sabluk V.T., Tanchyk S.P. Decrease of plant affection by diseases under fungal mycorrhization and symbiosis of their root system with nitrogen-fixing bacteria

Purpose. Reveal the effect of mycorrhization and nitrogen fixation of the root system of crops on the decrease of their affection by the most common diseases. Methods. Field, laboratory, and statistical. Results. According to the results of research, it was found that the mycorrhization of the crop root system significantly reduces their affection by the most common diseases. In particular, application of mycorrhizal fungi Trichoderma harzianum RIFAI, Tuber melanosporum Vittad., and nitrogen-fixing bacteria Bacillus subtilis Cohn., containing in biological products Mycofriend, Mikovital, and Florobacillin, respectively, have shown positive results in the decrease of the affection of soft winter wheat and maize by dangerous diseases such as root rots, powdery mildew, brown rust, blister smut, helminthosporium, etc. Thus, in 
the treatments with Mycofriend, Mikovital, and Florobacillin, the occurrence of diseases in soft winter wheat and maize was $4.4-21.3 \%$ less than in control and development $3.0-13.8 \%$ less than in control. Particularly noticeable was the decrease of winter wheat and maize affection by rust and helminthosporium, which in the treatments with mycorrhizal fungi and bacteria was 15.2-21.3\% less in terms of occurrence and $8.6-13.8 \%$ less in terms of development, compared to the control. Conclusions.
The main reason for the decrease of affection of crops by diseases under mycorrhization of their root system is their ability to withstand the infection by pathogens due to increased vital functions through improving provision with nutrients and moisture and more intensive process of photosynthesis, than in the control.

Key words: plants, helminthosporium, brown rust, blister rust, root rots, occurrence, diseases, mycorrhizal fungi, bacteria, affection. 